\title{
PENGATURAN PEMBERIAN PESANGON BAGI PEKERJA YANG MENGALAMI PHK PADA MASA PANDEMI COVID -19
}

\author{
Patricia Mara' Ayni Neysa, Fakultas Hukum Universitas Udayana, \\ e-mail: alohapatrice6@gmail.com \\ I Made Sarjana, Fakultas Hukum Universitas Udayana, \\ e-mail: made_sarjana@unud.ac.id
}

doi: https://doi.org/10.24843/KS.2020.v08.i11.p09

\begin{abstract}
ABSTRAK
Adapun tujuan penelitian ini yaitu untuk memahami pengaturan mengenai pemutusan hubungan kerja pada masa darurat kesehatan sebagai bentuk force majure dan untuk mengetahui pengaturan mengenai kewajiban perusahaan membayar pesangon bagi pekerja yang di Pemutusan Hubungan Kerja (PHK) pada masa Pandemi Covid-19 di Indonesia. Metode yang digunakan dalam penelitian ini yaitu jenis penelitian hukum normatif, dengan pendekatan perundang-undangan dan analisis konsep hukum serta metode analisis data deskriptif kualitatif. Hasil penelitian menunjukkan pengaturan PHK pada masa darurat kesehatan sebagai bentuk force majure dapat dilakukan oleh pengusaha atas pertimbangan perusahaan yang terancam tutup akibat pandemi covid-19 yang termasuk force majeure temporer. Ketentuan tersebut diatur pada pasal 151A huruf g dan pasal 154A huruf d Undang-Undang Cipta Kerja. Dalam hal pengaturan kewajiban perusahaan membayar pesangon bagi pekerja yang di PHK pada masa pandemi Covid-19 di Indonesia diatur dalam Pasal 153 ayat (1) sampai dengan Pasal 153 ayat (3) UUK sebagaiamana diubah dalam Undang-Undang Cipta Kerja pada pasal 153 ayat (1) sampai dengan Pasal 153 ayat (2).
\end{abstract}

Kata Kunci: Pandemi Covid-19, Pemutusan Hubungan Kerja, Pembayaran Pesangon

\begin{abstract}
The purpose of this study is to understand the arrangements regarding termination of employment during health emergencies as a form of force majure and to find out the arrangements regarding the company's obligation to pay severance pay for workers who are terminated during the Covid-19 Pandemic in Indonesia. used in this research is a type of normative legal research, with a statutory approach and analysis of legal concepts as well as descriptive qualitative data analysis methods. The results show that layoffs during a health emergency as a form of force majure can be carried out by employers on the consideration of companies that are threatened with closure due to the Covid-19 pandemic, which is a temporary force majeure. This provision is regulated in article 151A letter $g$ and article 154A letter $d$ of the Job Creation Law. In regulating the company's obligation to pay severance pay for workers laid off during the Covid-19 pandemic in Indonesia, it is regulated in Article 153 paragraph (1) to Article 153 paragraph (3) of the UUK as amended in the Job Creation Law in article 153 paragraph (1) up to Article 153 paragraph (2).
\end{abstract}

Keywords: Covid-19 Pandemic, Termination of Employment, Severance Payment.

\section{Pendahuluan}

\subsection{Latar Belakang}

Perkembangan sektor perekonomian suatu negara tidak dapat dilepaskan dari pembangunan sistem ketenagakerjaan yang memadai. Mengingat bahwa dalam menjalankan suatu roda perekonomian dengan salah satu bagiannya adalah adanya peran serta perusahaan dengan dukungan Sumber Daya Manusia (SDM) yang 
berkualitas, maka sistem ketenagakerjaan salah satu bagian penting untuk pembangunan sektor perekonomian suatu negara. Sehingga pembentukan sistem ketenagakerjaan memiliki banyak sudut pandang yang luas dan saling berkaitan. Hal tersebut tidak semata-mata adanya hubungan atas kepentingan para pihak, pra selama dan pasca masa kerja hubungan tersebut akan terjalin antara tenaga kerja, pengusaha dan pihak ketiga. Di dalam perusahaan, peran tenaga kerja amat penting dikarenakan dapat menunjang pembangunan system perusahaan yang baik. Peran sentral tenaga kerja, memiliki konsekuensi logis untuk ditingkatkan kualitas SDMnya dengan adanya jaminan kehidupan yang pasti. Jaminan ini seharusnya menjadi perlindungan tenaga kerja atas harkat dan martabatnya sebagai seorang manusia. ${ }^{1}$

Realisasi atas jaminan perlindungan tenaga kerja menciptakan suatu koneksi kerja antara pengusaha dan pekerja. Koneksi tersebut merupakan bentuk hubungan kerja yang berasal dari perjanjian kerja. Pada Pasal 1 angka 15 Undang-Undang Nomor 13 Tahun 2003 tentang Ketenagakerjaan (untuk selanjutnya disingkat UUK ), disebutkan bahwa antara pekerja dan pengusaha memiliki hubungan yang tertuang dalam suatu bentuk perjanjian kerja, dengan memiliki unsur-unsur adanya pekerjaan gaji dan perintah. ${ }^{2}$ Dalam pelaksanaannya hubungan tersebut tidak selamanya harmonis. Dikarenakan ada hal tertentu yang menyebabkan terjadinya ketidaksepahaman dalam menyikapi hubungan ketenagakerjaan tersebut. Biasanya hubungan pekerja dan pengusaha rentan dengan permasalahan misalnya adanya sengketa antara para pekerja dengan pengusaha atau perselisihan serikat kerja dalam suatu perusahaan. ${ }^{3}$ Tentu hal ini akan mengganggu produktivitas kerja dalam suatu perusahaan. Sehingga diperlukan langkah-langkah strategis untuk mengurangi permasalahan yang terjadi. Akan tetapi, realitasnya permasalahan yang sering terjadi di dalam suatu perusahaan yaitu antara bawahan dan atasan salah satunya terkait Pemutusan Hubungan Kerja (PHK). Itu adalah permasalahan yang sensitif antar para pihak, karena efek yang ditimbulkan menyebabkan permasalahan ikutan lainnya misalnya mengenai perlindungan hak tenaga kerja. Mengingat kejadian PHK yang paling bermasalah ketika salah satu pihak tidak menyepakati tindakan tersebut.

Dalam pandangan pekerja, terkadang pekerja PHK tidak menerima karena mereka tidak mendapat pemberitahuan terlebih dahulu dari pihak perusahaan. Selain itu pihak pekerjapun tidak mendapat jaminan atas hak-haknya pasca ter PHK dari pihak perusahaan. Mengingat banyak kasus pernah terjadi saat hak dari pekerja tak dipenuhi oleh perusahaan. Hal ini lah yang menyebabkan tenaga kerja tidak dapat menerima keputusan PHK tersebut. Pada dasarnya pengenaan PHK sangat berdampak pada kondisi finansial pekerja dan keluarganya, karena pekerja tersebut kehilangan mata pencaharian dan sumber penghasilan. Lebih lagi jika yang bersangkutan adalah satu-satunya tulang punggung keluarga. Apalagi saat ini lapangan pekerjaan yang tersedia relatif sedikit dibandingkan jumlah tenaga kerja yang mencari pekerjaan. Pada akhirnya pekerja yang ter-PHK dan tidak mendapatkan

1 Hulima, Dewi Indasari. "Perlindungan Hukum Bagi Tenaga Kerja Tidak Mendapatkan Pesangon oleh Perusahaan Menurut Undang-Undang Nomor 13 Tahun 2003." Lex Privatum 5, No.6 (2017): 109-116.

2 Suratman. Pengantar Hukum Ketenagakerjaan Indonesia. (Depok, PT. RajaGrafindo Persada, 2019), 60.

3 Utami, Tanti Kirana. "Peran Serikat Pekerja Dalam Penyelesaian Perselisihan Pemutusan Hubungan Kerja." Jurnal Wawasan Yuridika 28, No.1 (2015): 675-686. 
pekerjaan baru justru menjadi pengangguran yang berimplikasi terhadap meningkatnya jumlah pengangguran dan tingkat kemiskinan.

Sedangkan dari sisi pengusaha, tindakan PHK dikarenakan perusahaan memiliki permasalahan keuangan perusahaan, yang menyebabkan perusahaan harus melakukan efisiensi, termasuk efisiensi operasional dengan melakukan penciutan tenaga kerja. Dengan banyaknya yang ter-PHK yang memiliki masa kerja yang lama tentu hal ini dapat menyebabkan meningkatnya kompensasi yang harus disiapkan. Ilustrasi sederhananya adalah adanya besaran kompensasi yang wajib dibayar oleh pengusaha kepada para pekerjanya yang mengalami Pemutusan Hubungan Kerja. Resiko lain yang muncul bagi pengusaha akibat PHK adalah harus rela melepaskan pekerja yang berpengalaman, mencari pengganti yang belum tentu hasilnya lebih baik dan pasti akan menambah biaya rekrutmen yang tidak sedikit. Sebagaimana yang terjadi pada tahun 2020 ketika banyak kasus PHK yang terjadi akibat Pandemi Covid 19 yang melanda hampir semua negara-negara.

Mengawali tahun 2020, masyarakat dikejutkan oleh menyebarnya virus jenis baru yaitu coronavirus atau sering disebut juga Coronavirus disease 2019 (Covid-19). Virus ini berkembang berawal dari kota Wuhan, Tiongkok dan sampai sekarang sudah menyebar ke semua negara. ${ }^{4}$ Virus ini kemudian ditetapkan sebagai Pandemi oleh WHO, mengingat resiko yang sangat besar dan menyebabkan kekacauan pada semua bidang kehidupan seluruh dunia, termasuk di Indonesia. Kondisi ini ternyata menyebabkan gangguan pada sektor ekonomi dan mempengaruhi hampir seluruh sektor lainnya. ${ }^{5}$ Seiring berkembangnya virus ini dengan potensi yang mengganggu seluruh kegiatan sektor ekonomi di Indonesia.

Akibat dari Pandemi Covid 19 ini sebagian besar Pengusaha terpaksa untuk menghentikan atau mengurangi kegiatan usahanya. Dimana berarti akan terjadi Pemutusan Hubungan Kerja atau pengurangan para pekerjanya. Hal ini juga memaksa pekerja untuk Work From Home (WFH) atau tidak bekerja sama sekali. Kesimpulan yang dapat ditarik dari kejadian ini berkurangnya atau terhentinya sumber nafkah pekerja/buruh dan keluarganya akibat Pandemi Covid 19, bagi Pemerintah Pemutusan Hubungan Kerja adalah bertambahnya jumlah pengangguran yang dapat menimbulkan keresahan sosial. ${ }^{6}$ Adapun keresahaan sosial terjadi saat ini, bagi pekerja yang ter-PHK akan mendapatkan pesangon yang sesuai dengan ketentuan Pasal 156 ayat (1) UUK. Mengingat akan di masa Pandemic ini perusahaan mengalami kesulitan finansial sehingga pekerja yang ter-PHK merasa haknya tidak terjamin. Di sisi lain pengusaha tentu mengalami kesulitan keuangan sehingga terpaksa melakukan PHK, namun kondisi finansial yang tidak mendukung untuk membayarkan pesangon penuh kepada pekerja yang ter PHK. Hal ini didasarkan pada situasi pandemic Covid 19 yang termasuk kejadian luar biasa Non Bencana Alam yang dapat dikatakan sebagai Force Majure untuk pengusaha melakukan PHK dan tidak melakukan kewajibannya secara penuh terhadap pekerjanya yang ter-PHK. Sejatinya dalil tersebut perlu untuk

4 Baskara, Bima. "Rangkaian Peristiwa Pertama Covid-19." 2020 URL: "https:/ / bebas.kompas.id/baca/riset/2020/04/18/rangkaian-peristiwa-pertama-covid-19/" diakses pada tanggal 11 Juni 2020.

5 Putri, Nabila Nurul. "Dampak Pandemi Corona Terhadap Sektor Ekonomi Indonesia." 2020 URL: https://sukabumiupdate.com/detail/bale-warga/opini/67504-Dampak-PandemiCorona-Terhadap-Sektor-Ekonomi-Indonesia diakses pada tanggal 11 Juni 2020.

6 Prajnaparamitha, K, and Mahendra R Ghoni. "Perlindungan Status Kerja Dan Pengupahan Tenaga Kerja Dalam Situasi Pandemi COVID-19 Berdasarkan Perspektif Pembaharuan Hukum." Administrative Law \& Governance Journal3, No.2 (2020): 314-328. 
ditelaah kembali agar tercipta pengaturan yang jelas atas tindakan PHK yang dilakukan oleh pengusaha dalam masa Pandemi Covid-19. Berdasarkan pemaparan latar belakang tersebut, perlu dikaji kembali dengan mengangkat judul artikel ilmiah yaitu "Ketentuan Pemberian Pesangon Bagi Pekerja Yang Mengalami Pemutusan Hubungan Kerja Pada Masa Pandemi Covid-19"

Artikel ilmiah ini dibuat dengan judul Ketentuan Pemberian Pesangon Bagi Pekerja Yang Mengalami Pemutusan Hubungan Kerja Pada Masa Pandemi Covid-19 berdasarkan keinginan untuk memahami pengaturan PHK saat terjadi darurat kesehatan yang termasuk kategori force majure agar dapat menentukan seberapa jauh kewajiban perusahaan membayar pesangon bagi pekerja yang ter-PHK pada masa pandemi Covid-19. Penelitian ini tidak memiliki persamaan yang persis dengan publikasi ilmiah lainnya, baik judul maupun permasalahan yang dibahas pada jurnal Nasional maupun jurnal Internasional. Akan tetapi, publikasi ilmiah terkait masalah ketenagakerjaan yang terjadi selama pandemi terdapat publikasi yang membahasnya, salah satunya artikel karya Prajnaparamitha, K, and Mahendra R Ghoni dengan judul Perlindungan Status Kerja Dan Pengupahan Tenaga Kerja Dalam Situasi Pandemi COVID-19 Berdasarkan Perspektif Pembaharuan Hukum. Pada jurnal Administrative Law E Governance Journal Vol. 3 No.2 Tahun 2020 dengan rumusan masalahnya yaitu bagaimana perlindungan status kerja dan pengupahan tenaga kerja dalam situasi pandemi COVID-19 saat ini? dan Bagaimana perlindungan status kerja dan pengupahan tenaga kerja dalam situasi pandemi COVID-19 berdasarkan perspektif pembaharuan hukum? Dapat dilihat terdapat perbedaan judul dan rumusan masalah yang diteliti pada penelitian tersebut, sehingga penelitian ini merupakan karya orisinal dari penulis.

\subsection{Permasalahan}

1. Bagaimana pengaturan pemutusan hubungan kerja pada masa darurat kesehatan sebagai bentuk force majure?

2. Bagaimana pengaturan kewajiban perusahaan membayar pesangon bagi pekerja yang di PHK pada masa pandemi Covid - 19 di Indonesia?

\subsection{Tujuan Penelitian}

Tujuan artikel ilmiah ini untuk memahami ketentuan peraturan mengenai pemutusan hubungan kerja pada masa darurat kesehatan sebagai bentuk force majure dan untuk mengetahui pengaturan megenai kewajiban perusahaan membayar pesangon bagi pekerja yang di PHK pada masa Pandemi Covid-19 di Indonesia.

\section{Metode Penelitian}

Metode adalah hal mendasar pada hakikatnya bermakna memberikan pedoman dalam mempelajari, menganalisis, dan memahami hukum yang dimaksud. Dengan kata lain bahwa suatu ilmu dan pengetahuan didapatkan melalui penelitian dengan metode ilmiahnya. Dalam artikel ilmiah ini digunakan jenis penelitian hukum normatif, dengan pendekatan perundang-undangan dan analisis konsep hukum.7 Seluruh bahan hukum yang telah terkumpul dianalisa dengan metode analisis deskriptif kualitatif.

7 Susanti, Dyah Ochtorina and Efendi, A'an. Penelitian Hukum (Legal Research), Cetakan Ketiga (Jakarta, Sinar Grafika, 2018), 115. 


\section{Hasil Dan Pembahasan}

3.1 Pengaturan PHK Pada Masa Darurat Kesehatan Sebagai Bentuk Force Majure

Covid-19 pada dasarnya sudah ditetapkan oleh Presiden sebagai jenis penyakit yang tergolong sebagai situasi darurat kesehatan di masyarakat. ${ }^{8}$ Kondisi ini dapat dilihat pada Bagian Satu Keputusan Presiden Nomor 11 Tahun 2020 tentang Penetapan Kedaruratan Kesehatan Masyarakat Covid-19.Ketentuan ini merupakan pelaksanaan dari Undang-Undang Nomor 6 Tahun 2018 tentang Kekarantinaan Kesehatan ( UUKK) yang mengamanatkan ketentuan untuk menetapkan kedaruratan kesehatan masyarakat, atau mencabutnya atas sebuah penyakit sebagaimana diatur pada Pasal 10 ayat (4) hal tersebut dituangkan dalam bentuk Peraturan Pemerintah. Namun, dalam hal ini pemerintah menetapkan Covid-19 sebagai bentuk kedaruratan kesehatan masyarakat melalui keputusan presiden. Pada prinsipnya Covid-19 telah ditetapkan sebagai bentuk kedaruratan kesehatan masyarakat secara legal formal dalam keputusan presiden tersebut. Perlu dipahami Covid-19 sebagai penyakit yang telah memenuhi kondisi darurat kesehatan masyarakat, dikarenakan memenuhi rumusan Pasal 1 Angka (2) UUKK menyebutkan bahwa:

"Kedaruratan Kesehatan Masyarakat adalah kejadian kesehatan masyarakat yang bersifat luar biasa dengan ditandai penyebaran penyakit menular dan/atau kejadian yang disebabkan oleh radiasi nuklir, pencemaran biologi, kontaminasi kimia, bioterorisme, dan pangan yang menimbulkan bahaya kesehatan dan berpotensi menyebar lintas wilayah atau lintas negara."

Sebagai tindak lanjut atas ketetapan status tersebut, pemerintah menerbitkan Peraturan Pemerintah Nomor 21 Tahun 2020 tentang Pembatasan Sosial Berskala Besar dalam Rangka Percepatan Penanganan Corona Virus Disease 2019 (Covid-19) (untuk selanjutnya disebut PP PSBB). Kebijakan PSBB setidaknya meliputi pembatasan pembelajaran di sekolah, pembatasan aktivitas perkantoran atau bekerja, pembatasan untuk melakukan kegiatan ibadah keagamaan, dan/atau dibatasinya aktivita di ruang publik yang menggunakan fasilitas publik. Kebijakan ini dilaksanakan sebaik mungkin agar penyebaran virus ini dapat diminimalisasi, dengan seluruh tempat-tempat yang menimbulkan kerumunan dan tempat berkumpul sementara dihentikan. Dengan adanya PSBB, sektor yang paling berdampak adalah sektor perekonomian, karena seluruh tempat kerja terpaksa harus diliburkan, dan digantikan dengan kebijakan Work From Home(selanjutnya disingkat WFH). ${ }^{9}$ Kebijakan itu berlaku untuk sebagian pekerja, para pekerja yang tidak bekerja kantoran terpaksa harus dirumahkan atau terkena PHK. Dengan keadaan sulit seperti ini pengusaha mengambil tindakan PHK untuk pekerjanya adalah pilihan terakhir yang diambil, atas dasar berbagai pertimbangan seperti tidak adanya pemasukan yang menjadi profit untuk perusahaan seperti sebelum diberlakukannya PSBB. Melainkan, pengeluaraaan yang tetap berjalan sama seperti keadaan normal. Apalagi jika perusahaan tersebut merupakan pemain baru dalam dunia bisnis (baru memulai bisnisnya), dengan adanya kondisi keuangan yang sudah pasti mengalami penurunan omset yang drastis saat perusahaan tidak berjalan seperti sebagaimana mestinya dapat mengakibatkan kondisi perusahaan yang terancam pailit.

8 Randi, Yusuf. "Pandemi Corona Sebagai Alasan Pemutusan Hubungan Kerja Pekerja Oleh Perusahaan Dikaitkan Dengan Undang-Undang Ketenagakerjaan." Yurispruden: Jurnal Fakultas Hukum Universitas Islam Malang 3, No.2 (2020): 119-136.

9 Rohmah, Siti Ngainnur. "Adakah Peluang Bisnis di Tengah Kelesuan Perekonomian Akibat Pandemi Corona?." 'ADALAH 4, No.1 (2020): 63-74. 
Dalam hal ini, Pengusaha atas adanya kebijakan PSBB, wajib mematuhi keputusan yang diterapkan pemerintah yaitu dengan mempekerjakan pekerja dari rumah, dan membayar gaji pekerja yang WFH, akan tetapi belum tentu para pekerja yang WFH bekerja secara optimal. Maka dari itu, pengusaha harus melakukan efisiensi pengeluaran operasional dalam pengurangan jumlah pekerja yang pada masa darurat kesehatan ini tidak mendapat pemasukan seperti keadaan normal. Tentu pengusahatelah memiliki pertimbangan tersendiri dalam memilih para pekerjanya dalam artian memprioritaskan para pekerjanya. Pengusaha akan memilih pekerja yang memiliki pengaruh terhadap perusahaannya, memiliki kualifikasi yang dimiliki oleh perusahaan itu sendiri dan dapat menyelamatkan perusahaannya ditengah Pandemi seperti ini. Keputusan PHK di tengah Pandemi Covid 19 ini dapat tergolong sebagai Force Majeur sehingga perusahaan lebih mudah untuk melakukan PHK terhadap pekerjanya.

Bahwa sejak World Health Organization (WHO) menetapkan bahwa status pandemic dengan semakin banyaknya penyebaran Covid-19, seluruh aktivitas masyarakat kian terganggu. ${ }^{10}$ Tidak memungkiri aktivitas korporasi baik nasional maupun global harus ikut menerima dampak yang sangat besar karena merebaknya Covid-19. Pendapat dari Michael Hadilaya sebagai pengamat hukum, menyatakan bahwa Covid-19 sebagai pandemi sudah masuk kategori force majeure. Force Majeure dapat dikatakan sebagai keadaan kahar, yaitu kondisi dimana terjadi hal yang tidak dapat dikontrol oleh debitor karena berada diluar kendali kekuasaannya sehingga debitor tidak dapat melakukan prestasinya penuh. ${ }^{11}$ Menurut $\mathrm{R}$ Subekti, force majeure adalah keadaan yang diluar kekuasaan perusahaan bersifat memaksa, dan kondisi itu merupakan kondisi yang tidak dapat diprediksi saat waktu penyusunan perjanjian, setidaknya resiko tersebut tidak ditanggung oleh salah satu pihak. ${ }^{12}$ Berbeda dengan pendapat Johari Santoso dan Achmad Ali yang mengatakan keadaan kahar dapat dibedakan menjadi dua yaitu kahar mutlak dan kaha rtidak mutlak. ${ }^{13}$ Keadaan Kahar sejatinya telah diatur dalam Pasal 1244 KUHPerdata yaitu, mengatur tentang keadaan yang tidak dapat dimintakan pertanggungjawaban.

Keadaan kahar yang terjadi kepada pekerja yang di PHK pada masa darurat kesehatan tergolong keadaan kahar yang relatif. Keadaan kahar relatif artinya suatu kondisi yang menyebabkan debitor memiliki kemungkinan menjalankan prestasinya akan tetapi prestasi tersebut dilaksanakan dengan pengorbanan yang relatif lebih besar, yang menyebabkan ketidakseimbangan, yang memungkinkan debitor mengalami kerugian yang relatif tinggi (Relative Overmacht). Menurut Salim H.S. keadaan kahar relatif menggambarkan kondisi dimana dua hal dilakukan secara berbarengan dan sama-sama memerlukan pengorbanan yang setara. ${ }^{14}$ Sehingga, dalam hal PHK yang dilakukan oleh pengusaha saat pandemic Covid-19 dengan mem-PHK

10 Setyawati, Natalia. "Implementasi Sanksi Pidana Bagi Masyarakat Yang Beraktivitas Di Luar Rumah Saat Terjadinya Pandemi Covid-19." Jurnal Education And Development 8, No.2 (2020): 135-135.

11 Isradjuningtias, Agri Chairunisa. "Force Majeure (Overmacht) Dalam Hukum Kontrak (Perjanjian) Indonesia." Veritas et Justitia 1, No.1 (2015): 136-158.

12 Juaningsih, Imas Novita. "Analisis Kebijakan PHK Bagi Para Pekerja Pada Masa Pandemi Covid-19 di Indonesia." 'ADALAH 4, No. 1 (2020): 189-196.

13 Brahmana, Herman, et al. "Eskalasi Dan Force Majeur Dalam Perundang-Undangan Jasa Konstruksi." USU Law Journal 3, No.2 (2015): 78-86.

14 Hariri, Wawan Muham, Hukum Perikatan Dilengkapi Hukum Perikatan Dalam Islam, (Bandung, CV. Pustaka Setia, 2011), 108. 
pekerjanya ketika kondisi keuangan perusahaannya tidak stabil adalah bentuk pengorbanan yang dapat dilakukan untuk menyelamatkan perusahaan dan pekerja yang tidak ter-PHK. Atas dasar inilah PHK dalam masa Pandemi Covid-19 memenuhi kriteria relative overmacht sebagai bagian dari Force Majeure untuk melakukan tindakan PHK. Hal tersebut tidak termasuk kualifikasi ketentuan Pasal 164 ayat 3 UUK, mengingat PHK dilakukan di masa pandemi yang sejatinya telah diatur dalam pasal 164 ayat 1 UUK.

Akibat dari Force Majuere teradapat dua kemungkinan yaitu penundaan kewajiban dan pengakhiran perjanjian. Penundaan kewajiban terjadi ketika peristiwa keadaan kahar ini bersifat sementara, apabila keadaan telah kembali normal, kewajiban akan dijalankan sesuai dengan perjanjian. Sedangkan Berakhirnya suatu perjanjian terjadi ketika halangan bersifat tetap. Contohnya Gus adalah penyanyi sudah menandatangani kontrak untuk menyanyi dalam pentas seni, akan tetapi diluar dugaan Gus sakit dan harus melakukan operasi pita suara, sehingga Gus tidak memungkinkan lagi untuk bernyanyi. Dengan berakhirnya perjanjian, maka kontrak prestasi juga akan ikut berakhir, misalnya kewajiban pihak penyelenggara pentas seni untuk membayar penyanyi tersebut. Pendapat tersebut menguatkan jenis force majeure dari segi jangka waktu berlakunya. Force Majeure berdasarkan jangka waktu berlakunya di bagi menjadi dua yaitu force majeure permanen dan force majeure temporer. Jadi bila kita lihat dari segi jangka waktunya, PHK ditengah masa pendemi Covid 19 ini tergolong sebagai force majeure yang temporer. Mengingat perusahaan yang melakukan PHK terhadap pekerjanya di tengah darurat kesehatan seperti ini, asalkan adanya pemberitahuan yang jelas akan PHK itu sendiri, pemenuhan akan pesangon-pesangonnya dipenuhi serta melakukan PHK sesuai tahapan-tahapan yang sudah diatur pada BAB XII UUK tentang Pemutusan Hubungan Kerja.

Menurut Abdul Khakin yang menjelaskan ada beberapa tahap dalam pelaksanaan PHK yaitu:

a. Lebih dahulu para pihak, yaitu pihak pengusaha dan pekerja harus melakukan tindakan untuk menghindari adanya PHK;

b. Jika PHK tidak dapat dipungkiri, pihak pengusaha dan pekerja harus melaksanakan perembukan bersama;

c. Bila perembukan berhasil, dapat dibuat persetujuan bersama;

d. Namun bila perembukan tidak berhasil, pengusaha dapat mengajukan permohonan penetapan disertai dasar dan alasanya kepada lembaga penyelesaian perselisihan hubungan industrial;

e. Semasih tidak adanya penetapan dan putusan dari lembaga penyelesaian perselisihan hubungan industrial, pihak pengusaha dan pekerja tetap melaksanakan segala kewajibannya masing-masing, dimana para pekerja tetap menjalankan pekerjaanya dan pengusaha tetap membayar upah.

Secara teknis yuridis pelaksanaan PHK itu sendiri juga merujuk pada ketentuan Pasal 151 dan 152 UUK. Sebagaimana diketahui ketentuan tersebut diubah dalam UndangUndang Cipta Kerja dengan mengubah pasal 151 dan menyisipkan pasal 151A dan menghapus pasal 152 UUK. Ketentuan perubahan tersebut pada prinsipnya masih memiliki persamaan dengan ketentuan sebelumnya. Untuk pengusaha melakukan PHK karena terancam perusahaan tutup yang ditimbulkan akibat adanya force majeur merujuk pada ketentuan pasal 151A huruf g dan pasal 154A huruf d Undang-Undang Cipta Kerja. 
Oleh karena itu, alasan PHK dalam darurat kesehatan ini dapat dilakukan dengan memperhatikan prosedur PHK, sebagaimana diatur dalam Undang-Undang Cipta Kerja dengan mengubah pasal 151 dan menyisipkan pasal 151A dan menghapus pasal 152 UUK. Dalam hal pengusaha melakukan PHK karena terancam perusahaan tutup yang ditimbulkan akibat adanya force majeur merujuk pada ketentuan pasal 151A huruf g dan pasal 154A huruf d Undang-Undang Cipta Kerja. Mengingat Pandemi Covid-19 ini disebutkan secara tegas adalah wabah penyakit yang menyebabkan seluruh aktivitas masyarakat kian terganggu dan penutupan berbagai sektor. Serta oleh pemerintah Indonesia ditetapkan sebagai kedaruratan kesehatan masyarakat, sehingga Pandemi Covid-19 dapat dijadikan sebagai alasan force majeur untuk perusahaan dengan melakukan kebijakan PHK untuk sebagian pekerja. Bila dipaksakan sebuah perusahaan beroperasional seperti biasanya menimbulkan bahaya yang sangat besar bagi seluruh pekerjanya.

\subsection{Pengaturan Kewajiban Perusahaan Membayar Pesangon bagi pekerja yang di PHK pada masa Pandemi Covid-19 di Indonesia}

Hubungan antara pengusaha dengan pekerja yang terikat pada perjanjian kerja, tentu menganduk hak dan kewajiban bagi pengusaha maupun pekerja selama ataupun sesudah perjanjian itu berakhir. Dalam hal berakhirnya suatu perjanjian kerja, hal ini dapat terjadi sebagaimana ketentuan Pasal 61 ayat (1) UUK yang dimana salah satu penyebabnya perjanjian kerja karena adanya kejadian tertentu yang menyebabkan berakhirnya hubungan kerja. Mengacu pada ketentuan tersebut bahwa PHK yang dilakukan selama Pandemi Covid-19 ini dapat dilakukan selama perjanjian itu mencantumkan klausul force majeure sebagai pengatur pengakhiran perjanjian kerja. Apabila pengusaha melakukan PHK yang berarti memutus perjanjian kerja secara sepihak, meskipun dengan dalil force majeure dalam hal ini pandemi Covid-19 ini pengusaha tetap dibebankan dengan kewajiban untuk memenuhi kewajibannya terhadap pekerja yang ter-PHK, agar hak-hak ter-PHK dilindungi dan Kewajiban pengusaha terlaksana sebagaimana yang diatur dalam UUK.

Maksud dari rangka memberikan suatu kepastian terhadap kewajiban dan hak antara pekerja dan pengusaha di dalam perusahaan harus memiliki arahan yang jelas sebagaimana diatur dalam bentuk Peraturan Perusahaan. Suatu peraturan perusahaan yang telah dibuat dan disahkan dapat dijadikan pedoman dalam pelaksanaan hubungan kerja dalam perusahaan. Salah satu yang termuat dalam peraturan perusahaan adalah kewajiban dari pengusaha, kewajibannya yaitu Pada awalnya memberikan info serta memberikan penjelasan akan isi yang termuat dalam peraturan perusahaan kepada seluruh pekerja, Selanjutnya mendistribusikan buku yang berisikan peraturan dari perusahaan itu sendiri kepada semua pekerjanya, dan yang terakhir melaksanakan isi dari peraturan perusahaan sebaik mungkin serta penuh tanggung jawab.15

Oleh karena itu pengusaha wajib untuk melaksanakan kewajibannya terhadap pemenuhan hak pekerja yang ter-PHK yaitu memenuhi pembayaran pesangon. Sebagaimana ketentuan Pasal 1 Angka 25 UUK bahwa PHK adalah pengakhiran relasi kerja disebabkan suatu kondisi tertentu yang mengakibatkan berakhirnya kewajiban

15 Zulkarnaen, Ahmad Hunaeni. "Penyuluhan Tentang Tata Cara Membuat Peraturan Perusahaan Di PT. Pelangi Warna Kreasi Bandung." Journal of Empowerment, 1, No.1 (2017): 3746. 
dan hak antara pekerja dan pengusaha. ${ }^{16}$ Dalam Masa Pandemi Covid-19 dapat dilakukan PHK sebagaimana kategori Covid-19 yang tergolong Force Majeure Relative. Kewajiban pengusaha terhadap karyawan yang ter-PHK untuk membayar pesangon diatur dalam Pasal 164 ayat (1) UUK yang telah dihapus dan telah ditegaskan dalam Pasal 156 Undang-Undang Cipta Kerja yang pada prinsipnya memiliki persamaan dengan ketentuan Pasal 156 UUK. Ketentuan tersebut menyatakan bahwa bagi pengusaha dapat melakukan PHK dikarenakan perusahaan tidak mengalami keuntungan tetapi menghadapi kerugian secara terus menerus, ataupun karena perusahaan akan tutup, atau perusahaan mengalami keadaan memaksa yang menyebabkan pekerja harus ter PHK dengan tetap memenuhi hak pekerja atas uang pesangon, uang penghargaan dan uang pengganti hak sebesar masing-masing satu kali. ${ }^{17}$ Hal ini ditegaskan pada Pasal 156 ayat (1) UUK yang menyatakan ketika terjadi PHK, Upah Penghargaan Masa Kerja, Upah Pengganti Hak dan Uang Pengganti Kewajiban yang wajib dibayarkan oleh pengusaha sebagaimana yang diterima oleh pekerja.

Selain itu ketentuan pemberian pesangon, juga diatur pada Pasal 156 ayat (2) UUK yang tegas mengatur perhitungan uang pesangon dengan nominal minimum disesuaikan dengan masa kerjanya. Bahwa semakin lama masa kerja seorang pekerja di perusahaan, pengusaha pun harus mengeluarkan uang pesangon lebih besar kepada pekerja yang masa kerjanya tergolong lama. Besaran uang pesangon yang terdapat pada Pasal 156 ayat (2) UUK dimaksud disini adalah jumlah gaji pokok yang telah ditambah dengan tunjangan tetap, seperti tunjangan jabatan, transportasi, makan, kesehatan, dan lainnya. Lebih lanjut ketentuan Pasal 156 ayat (3) UUK menetapkan bahwa perhitungan uang masa kerja berdasarkan pada lamanya waktu bekerja di perusahaan terebut, untuk menentukan nominal uang penghargaan masa kerja. Ketentuan tersebut menentukan tentang uang penghargaan masa kerja, seorang pekerja tidak sekedar menerima gaji setiap bulan dan tunjangan saja, sebagai pekerja pada dasarnya memiliki hak atas penghargaan yang musti didapatkannya. Maka dari itu, perhitungan akan uang penghargaan masa kerja oleh masing-masing perusahaan mengacu pada ketentuan ini termasuk perusahaan yang melakukan PHK dalam masa Pandemi Covid-19. Selanjutnya dalam Pasal 156 ayat (4) UUK mengatur mengenai uang pengganti para pekerja yang menjadi hak pekerja dan kewajiban perusahaannya untuk membayarnya atas hal sebagaimana diatur dalam ketentuan tersebut. Dalam menjalankan kewajiban tersebut, pastinya perusahaan memiliki kesulitan dalam menjalankan kewajibannya. Pada kewajiban pembayaran uang pesangon untuk sebagian karyawan yang ter PHK sekaligus adalah beban yang lumayan berat, karena pengeluaran yang dikeluarkan untuk membayar pesangon para pekerja tidak sebanding dengan pemasukan yang ada saat ini. Di tengah Pandemi seperti ini pastinya banyak kewajiban yang harus dilaksanakan oleh perusahaan, karena alasan ini perusahaan memilih kewajiban yang dianggap perusahaan paling urgensi untuk dilakukan tanpa harus melupakan kewajiban yang lain. Maka dari itu perusahaan memilih jalan untuk membayar kewajiban pesangon secara bertahap atau ditunda

16 Zaini, Ahmad. "Pengaturan Pemutusan Hubungan Kerja (PHK) Menurut Peraturan Perundangan-undangan Ketenagakerjaan." Al-Ahkam 13, No.1 (2017): 76-110.

17 Mogi, Erica Gita. Perlindungan Hukum Terhadap Tenaga Kerja yang dilakukan Pemutusan Hubungan Kerja Sepihak oleh Perusahaan Menurut UU No 13 Tahun 2003 tentang Ketenagakerjaan. Lex Administratum, 5, No.2 (2017): 61-68. 
sampai situasi saat ini yang tergolong force majeure temporer dinyatakan selesai. Kewajiban pesangon yang tertunda yang tergolong force majeure temporer dapat dilakukan di kemudian hari dengan kesepakatan para pihak.

Dalam hal persyaratannya mengenai pembayaran pesangon tenaga kerja yang ter-PHK tertuang pada pasal 156 ayat (2) sampai dengan pasal 156 ayat (3) UUK, dapat kita lihat bahwa dalam ketentuan tersebut tidak mengatur secara spesifik mengenai adanya penundaan pembayaran pesangon atau kapan persisnya upah pekerja yang ter-PHK dibayarkan. Akan tetapi ketika perusahaan mengalami banyak kerugian selama masa pandemic Covid-19 dapat menunda pembayaran pesangon dengan melakukan perundingan yang tertuang dalam suatu perjanjian. Menyikapi hal dalam pembayaran Pesangon, ada baiknya antara pekerja dan pengusaha melakukan perundingan, agar tidak terjadi adanya perselisihan. Dalam hal force majeure yang mengakibatkan terjadinya PHK, meskipun sudah diupayakan tidak terjadi PHK akan tetapi kepentingan dari perusahaan untuk mengefisiensikan dan menyelamatkan karyawan yang lainnya maka dalam rangka pengefisenan jumlah pekerja, atas hal tersebut pihak pengusaha dan pihak karyawan yang ter-PHK melakukan negosiasi untuk melakukan perjanjian dimana perusahaan gimana caranya karyawan meminta pesangon pembayaran seketika atau bagaimana. Dalam hal force majeure yang mengakibatkan terjadinya PHK, meskipun sudah diupayakan tidak terjadi PHK, namun untuk kepentingan dari perusahaan untuk mengefisiensikan dan menyelamatkan karyawan yang lainnya maka dalam rangka pengefisienan jumlah pekerja atas hal tersebut pihak pengusaha dan pihak karyawan yang ter-PHK dapat melakukan negosiasi untuk melakukan perjanjian yang dimana perusahaan tetap membayarkan pesangonnya namun dengan memberikan tenggang waktu untuk pelunasannya yang tertuang dalam bentuk perjanjian.

Menurut pendapat Wakil Ketua Umum Kadin Indonesia Bidang Hubungan Internasional Shinta Kamdani,karena virus di indonesia ini masih tinggi penyebarannya maka kondisi ekonomi masih tertekan, maka tindakan phk tidak dapat dihindari oleh perusahaan hanya ada dua pilihan untuk perusahaan yaitu gulung tikar atau pailit. ${ }^{18}$ Berbeda dengan pendapat Wakil Ketua Bidang Ketenagakerjaan APINDO Bob Azam, pihak pengusaha dan pekerja harus melakukan perundingan untuk mencari win-win solution untuk kedua belah pihak, karena situasi seperti ini merupakan masa sulit untuk pengusaha maupun pekerja. Beliau juga menuturkan bahwa untuk para pekerja hanya memiliki dua pilihan, apakah menjadi pekerja dengan segala keterbatasan atau pekerja yang ter PHK dengan pesangon. ${ }^{19}$ Maka dari itu, untuk menghindari pengusaha gagal bayar uang pesangon, uang penghargaan dan uang pengganti hak pekerja yang ter-PHK selama mengalami kondisi keuangan perusahaan yang tidak stabil, pengusaha dapat melaksanakan perubahan besaran maupun cara pembayaran kewajiban tersebut, berdasarkan kesepakatan para pihak.

18 Damhuri, Elba. "Dampak Virus Corona: Berpacu Mencegah PHK Massal " URL: https://republika.co.id/berita/q8kh09440/dampak-virus-corona-berpacu-mencegah-phkmassal, diakses tanggal 26 Juni 2020.

${ }^{19}$ Priyanka, Adinda and Riska Yovianda "Hadapi Potensi PHK,Pengusaha buka diskusi dengan pegawai" URL: https://republika.co.id/berita/q8kak5370/hadapi-potensi-phkpengusaha-buka-diskusi-dengan-pegawai, diakses tanggal 26 Juni 2020. 


\section{Kesimpulan}

Pengaturan pemutusan hubungan kerja pada masa darurat kesehatan sebagai bentuk force majure dapat dilakukan oleh pengusaha atas pertimbangan perusahaan yang terancam tutup akibat pandemi Covid-19 yang termasuk force majeure dan boleh dilakukan sebagaimana yang diatur dalam Pasal 151A huruf g dan Pasal 154A huruf d Undang-Undang Cipta Kerja, yang mengubah ketentuan Pasal 151 dan 154 UUK. Dalam hal pengaturan kewajiban perusahaan membayar pesangon bagi pekerja yang di PHK pada masa pandemic Covid -19 di Indonesia diatur dalam Pasal 153 ayat (1) sampai dengan Pasal 153 ayat (3) UUK, yang tidak diubah dalam Pasal 153 UndangUndang Cipta Kerja. Dalam hal kewajiban tersebut belum mampu terpenuhi maka perusahaan dapat mengajukan penangguhan pembayaran uang pesangon atau pelaksanaan kewajiban tersebut kepada pekerja dengan melakukan perundingan terlebih dahulu dan dituangkan dalam bentuk perjanjian. Adapun saran untuk situasi sekarang ini adalah adanya gotong royong akan mengedepankan dialog sosial untuk mencari solusi terbaik untuk menghindari adanya PHK. Dalam rangka mencegah adanya PHK, Kementerian Ketenagakerjaan telah mempublikasikan Surat Edaran Menteri Ketenagakerjaan Nomor M/3/HK.04/III/2020 Tahun 2020 tentang Perlindungan Pekerja/Buruh dan Kelangsungan Usaha dalam Rangka Pencegahan dan Penanggulangan Covid-19.

\section{Daftar Pustaka}

Buku

Hariri, Wawan Muham. Hukum Perikatan Dilengkapi Hukum Perikatan Dalam Islam. (Bandung, CV. Pustaka Setia, 2011).

Suratman. Pengantar Hukum Ketenagakerjaan Indonesia. (Depok, PT. RajaGrafindo Persada, 2019).

Susanti, Dyah Ochtorina and Efendi, A'an. Penelitian Hukum (Legal Research), Cetakan Ketiga, (Jakarta, Sinar Grafika, 2018).

\section{Jurnal}

Brahmana, Herman, et al. "Eskalasi Dan Force Majeur Dalam Perundang-Undangan Jasa Konstruksi." USU Law Journal 3, No. 2 (2015).

Hulima, Dewi Indasari. "Perlindungan Hukum Bagi Tenaga Kerja Tidak Mendapatkan Pesangon oleh Perusahaan Menurut Undang-Undang Nomor 13 Tahun 2003." Lex Privatum 5, No. 6 (2017).

Isradjuningtias, Agri Chairunisa. "Force Majeure (Overmacht) Dalam Hukum Kontrak (Perjanjian) Indonesia." Veritas et Justitia 1, No. 1 (2015).

Juaningsih, Imas Novita. "Analisis Kebijakan PHK Bagi Para Pekerja Pada Masa Pandemi Covid-19 di Indonesia." 'ADALAH 4, No. 1 (2020).

Mogi, Erica Gita. "Perlindungan Hukum Terhadap Tenaga Kerja yang dilakukan Pemutusan Hubungan Kerja Sepihak oleh Perusahaan Menurut UU No 13 Tahun 2003 tentang Ketenagakerjaan." Lex Administratum, 5, No. 2 (2017).

Prajnaparamitha, K, and Mahendra R Ghoni. "Perlindungan Status Kerja Dan Pengupahan Tenaga Kerja Dalam Situasi Pandemi COVID-19 Berdasarkan Perspektif Pembaharuan Hukum." Administrative Law \& Governance Journal 3, No. 2 (2020).

Randi, Yusuf. "Pandemi Corona Sebagai Alasan Pemutusan Hubungan Kerja Pekerja

Oleh Perusahaan Dikaitkan Dengan Undang-Undang Ketenagakerjaan." Yurispruden: Jurnal Fakultas Hukum Universitas Islam Malang 3, No. 2 (2020). 
Rohmah, Siti Ngainnur. "Adakah Peluang Bisnis di Tengah Kelesuan Perekonomian Akibat Pandemi Corona?" 'ADALAH 4, No. 1 (2020).

Setyawati, Natalia. "Implementasi Sanksi Pidana Bagi Masyarakat Yang Beraktivitas Di Luar Rumah Saat Terjadinya Pandemi Covid-19." Jurnal Education And Development 8, No. 2 (2020).

Utami, Tanti Kirana. "Peran Serikat Pekerja Dalam Penyelesaian Perselisihan Pemutusan Hubungan Kerja." Jurnal Wawasan Yuridika 28, No.1 (2015).

Zaini, Ahmad. "Pengaturan Pemutusan Hubungan Kerja (PHK) Menurut Peraturan Perundangan-undangan Ketenagakerjaan." Al-Ahkam 13, No. 1 (2017).

Zulkarnaen, Ahmad Hunaeni. "Penyuluhan Tentang Tata Cara Membuat Peraturan Perusahaan Di PT. Pelangi Warna Kreasi Bandung." Journal of Empowerment, 1, No. 1 (2017).

\section{Internet}

Baskara, Bima. "Rangkaian Peristiwa Pertama Covid-19." 2020 URL: "https:// bebas.kompas.id/baca/riset/2020/04/18/rangkaian-peristiwapertama-covid-19/" diakses pada tanggal 11 Juni 2020.

Damhuri, Elba. "Dampak Virus Corona: Berpacu Mencegah PHK Massal " URL: https://republika.co.id/berita/q8kh09440/dampak-virus-corona-berpacumencegah-phk-massal, diakses tanggal 26 Juni 2020.

Priyanka, Adinda and Riska Yovianda "Hadapi Potensi PHK,Pengusaha buka diskusi dengan pegawai" URL: https://republika.co.id/berita/q8kak5370/hadapipotensi-phk-pengusaha-buka-diskusi-dengan-pegawai, diakses tanggal 26 Juni 2020.

Putri, Nabila Nurul. "Dampak Pandemi Corona Terhadap Sektor Ekonomi Indonesia." 2020 URL: https://sukabumiupdate.com/detail/bale-warga/opini/67504Dampak-Pandemi-Corona-Terhadap-Sektor-Ekonomi-Indonesia diakses pada tanggal 11 Juni 2020.

\section{Peraturan Perundang-Undangan}

Republik Indonesia, Undang-Undang Tentang Ketenagakerjaan, Undang-Undang Nomor 13 Tahun 2003, Lembaran Negara Republik Indonesia Tahun 2003 Nomor 39, Tambahan Lembaran Negara Republik Indonesia Nomor 4279.

Republik Indoneisa, Undang-Undang Cipta Kerja, Undang - Undang Nomor .... Tahun 2020, Lembaran Negara Republik Indonesia Tahun 2020 Nomor ...., Tambahan Lembaran Negara Republik Indonesia Nomor ....

Republik Indonesia, Surat Edaran Menteri Ketenagakerjaan Nomor M/3/HK.04/III/2020 Tahun 2020 tentang Perlindungan Pekerja/Buruh dan Kelangsungan Usaha dalam Rangka Pencegahan dan Penanggulangan Covid19, 